\title{
Anti-acne activity of Garcinia mangostana L.: A review
}

\author{
Panupon Khumsupan and Wandee Gritsanapan ${ }^{\varpi}$
}

\begin{abstract}
Garcinia mangostana L. or mangosteen of the Clusiaceae has traditionally been employed as medicinal drugs for decades. A plethora of compounds are responsible for a wide range of medicinal properties and biological activities. The ethanol extract of the mangosteen rind has been found to be anti-inflammatory, antioxidant and anti-acne-causing bacteria. Many research studies have confirmed its potency, with the ethanol extract of the rind being able to inhibit pro-inflammatory cytokines (TNF- $\alpha$ ) at relatively low concentration. DPPH assay also revealed its potent radical scavenging activity. The compound responsible for the antibacterial activity, $\alpha$-mangostin, was especially potent and one of the compounds responsible for the anti-bacterial activity.
\end{abstract}

Keywords: Garcinia mangostana; mangosteen; acne.

\section{Introduction}

Garcinia mangostana L., colloquially known as mangosteen, is one of the most economical tropical fruits among the Southeast Asian countries (Somsri \& Manassakorn, 2006). Famously known for its sweet taste and uniquely pleasant aroma, it had been given a title "The queen of fruits." In addition to being popularly consumed, it also contains invariably nutritious compounds that are beneficial for the body. Many parts of the plant have long

Received: 29 April 2014 / Accepted revised version: 24 June 2014 / Published online: 14 August 2014

(C) Horizon e-Publishing Group

CITATION

Khumsupan, P., \& Gritsanapan, W. (2014). Anti-acne activity of Garcinia mangostana L.: A review. Plant Science Today, 1(3), 147-150. http://dx.doi.org/10.14719/pst.2014.1.3.39

\section{AUTHORS' AFFILIATION}

Department of Pharmacognosy, Faculty of Pharmacy, Mahidol University, Bangkok 10400, Thailand

CORRESPONDENCE

D Dr. W. Gritsanapan Tel. +662 6448677-89 ext 1500, 5530 Fax +66 2 6448701 E-mail : wandee.gri@mahidol.ac.th; wandeegrit@yahoo.co.th been utilized ethnologically as medicinal herb. For instance, dried powder fruit hull has been used as a wound-healing agent, to treat skin infection, suppuration and chronic ulcer (Saralamp, Chuakul, Temsiiririkkul, \& Clayton, 1996). Leaves and bark are strongly anti-inflammatory and the ointment derived from them can be used to treat eczema, hyperkeratosis and psoriasis. The root decoction is administered to treat menstrual disorder (Farnworth \& Bunyapraphatsara, 1992). The tea made from fruits is used as tonic for fatigue and low energy state, to aid digestive system and to treat parasitic skin infection (Obolskiy, Pischel, Siriwatanametanon, \& Heinrich, 2009). Botanically, mangosteen is a small to medium height evergreen tree, 6-25 m, sap yellow with a straight trunk, symmetrically branched to form a conical crown. All parts of the plant contain yellow latex (Somsri \& Manassakorn, 2006).

\section{Compounds in G. mangostana}

Technological advances in chromatography and structural elucidation have given tremendous insight to active constituents responsible for myriad of the aforementioned medicinal properties. Much of the focus has been given to the rind since it is consumption byproduct and could be readily utilized. More than sixty xanthones have been elucidated in addition to tannins, flavonoids, and phenolic compounds, which are responsible for mangosteen's anti-inflammatory and antioxidant activities. Some of the compounds found especially in the rind, for example, the major compound, $\alpha$-mangostin, have also been labeled to be anti-bacterial against acne-causing bacteria (Jung, Su, Keller, Mehta, \& Kinghorn, 2006; Peres, Nagem, \& de Oliveira, 2000; Vieira \& Kijjoa, 2005).

\section{Biological activities}

The area of study of exploiting mangosteen rind to treat acne is relatively new and a lot of studies have yet to be conducted to find out which individual compound contributes to the anti-acne activity. However, the major compound $\alpha$-mangostin has been ascertained to be 
formidably active against acne-causing bacterial, Propinobacterium acnes and Staphelococcus epidermidis (Chomnawang, Surassmo, Nukoolkarn, \& Gritsanapan, 2005). Altogether, the anti-inflammatory (Chomnawang, Surassmo, Nukoolkarn, \& Gritsanapan, 2007), antioxidant and antibacterial properties (Pothitirat, Chomnawang, Supabphol, \& Gritsanapan, 2010) directly target acne's pathogeneses. When used in conjunction with an agent that promotes epidermal desquamation, $\alpha$-mangostin could boast a potentially potent or even commercially beneficial active medicinal compound.

Table 1: Systematic classification (taxonomy) of $G$. mangostana (USDA, 2014)

\begin{tabular}{|c|c|}
\hline Taxon & \\
\hline Kingdom & Plantae \\
\hline Subkingdom & Tracheobionta \\
\hline Superdivision & Spermatophyta \\
\hline Division & Magnoliophyta \\
\hline Class & Magnoliopsida \\
\hline Subclass & Dilleniidae \\
\hline Order & Theales \\
\hline Family & Clusiaceae (Guttiferae) \\
\hline Genus & Garcinia \\
\hline Species & Garcinia mangostana Linn. \\
\hline
\end{tabular}

Chomnawang, et al. investigated the effectiveness of $G$. mangostana in comparison with six other medicinal plants and found that G. mangostana was the leading candidate against acne. At the concentration of $50 \mu \mathrm{g} / \mathrm{ml}$ of crude ethanol extract, it was able to inhibit $99.59 \%$ of pro-inflammatory cytokines (TNF- $\alpha$ ) produced by human peripheral blood mononuclear cells. DPPH scavenging assay also revealed its potent antioxidant activity, with the half-maximal inhibitor concentration $\left(\mathrm{IC}_{50}\right.$ ) of $6.13 \mu \mathrm{g} / \mathrm{ml}$ and $77.80 \pm 1.28 \%$ superoxide radical inhibition ratio, the lowest among medicinal herbs tested (Chomnawang et al., 2005).

The antibacterial activity of $G$. mangostana has also been investigated by Pothitirat et al. Fruit rinds from thirteen different locations in Thailand were extracted with ethanol and tested against $P$. acnes and S. epidermidis. The average minimum inhibitory concentration (MIC) and minimum bactericidal concentration (MBC) against $P$. acnes were $13.22 \mu \mathrm{g} / \mathrm{ml}$ and $18.82 \mu \mathrm{g} / \mathrm{ml}$, respectively, while those against $S$. epidermidis were $24.04 \mu \mathrm{g} / \mathrm{ml}$ and $86.54 \mu \mathrm{g} / \mathrm{ml}$, respectively. However, pure $\alpha$-magostin displayed a highly potent activity, having the MIC and MBC of $1.95 \mu \mathrm{g} / \mathrm{ml}$ against $P$. acnes and $3.91 \mu \mathrm{g} / \mathrm{ml}$ against $S$. epidermidis. From this, it could be inferred that $\alpha$-magostin is one of the contributing compounds responsible for the anti-acne activity in mangosteen extract (Pothitirat, Chomnawang, \& Gritsanapan, 2008).
Extraction method and solvent used give rise to differences in terms of $\alpha$-mangostin content and hence, biological activity. It would seem like $\alpha$-mangostin, phenolics and tannins in the rind are relatively tolerable to heat since Soxhlet extraction method did not hinder the extraction of these compounds compared to other methods where heat was not applied. The extract from Soxhlet extraction using $50 \%$ ethanol also promoted the lowest effective concentration that gives half-maximal response $\left(\mathrm{EC}_{50}\right) \quad 12.84 \pm 0.08 \mu \mathrm{g} / \mathrm{ml}$ tested by DPPH-scavenging assay. The extract of $95 \%$ ethanol from Soxhlet extraction also promoted the lowest MIC against $P$. acnes, $7.81 \mu \mathrm{g} / \mathrm{ml}$ (Pothitirat et al., 2010).

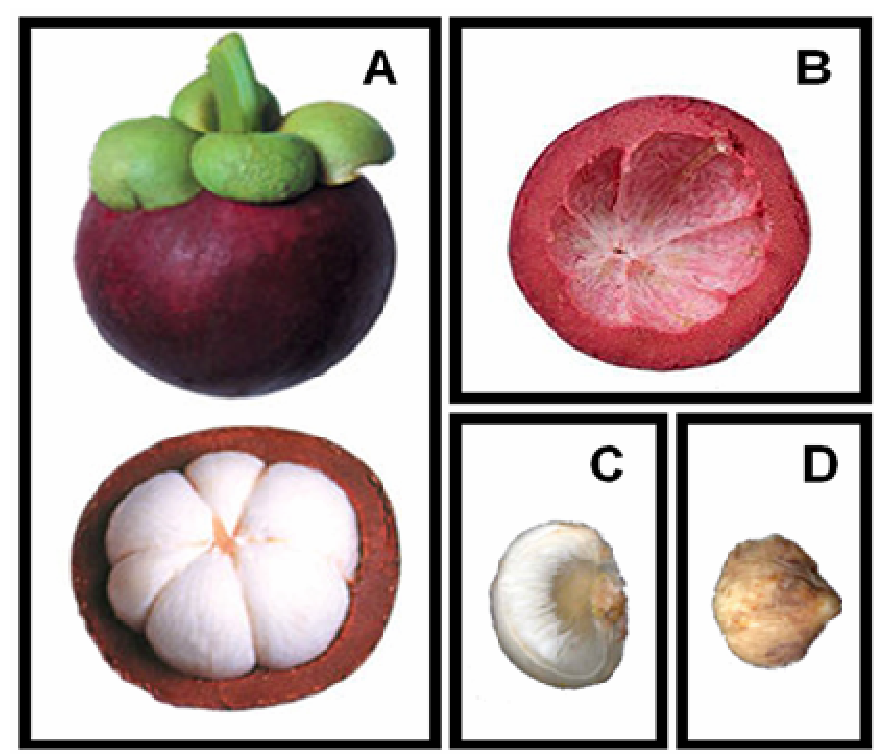

Fig 1. Mangosteen fruit (A), rind (B), pulp (C), and seed

(D)

The investigation on the solvent that would yield the highest amount of $\alpha$-mangostin was also performed and it was found that dichloromethane was the solvent that yielded $46.21 \pm 2.46 \%$ of $\alpha$-mangostin $\mathrm{w} / \mathrm{w}$ of extract. This number is much higher than other solvents, hexane and ethanol, and very likely was the reason for dichloromethane extract's lower MIC and MBC against both $P$. acnes $(3.91 \mu \mathrm{g} / \mathrm{ml}$ ) and $S$. epidermidis (3.91 and $15.63 \mu \mathrm{g} / \mathrm{ml}$, respectively) (Pothitirat et al., 2008).

Apparently, different maturity stages also affected the amount of active constituents in the rind. Young mangosteen rind contained less $\alpha$-mangostin $(8.07 \pm 0.11$ vs $13.63 \pm 0.06 \% \mathrm{w} / \mathrm{w}$ of extract) and flavonoids (2.91 \pm 0.09 vs $4.08 \pm 0.07 \mathrm{~g} \mathrm{QE} / 100 \mathrm{~g}$ extract) but more phenolics $(42.57 \pm 0.11$ vs $28.88 \pm 0.73 \mathrm{~g} \mathrm{GAE} / 100 \mathrm{~g}$ extract $)$ and tannins ( $51.25 \pm 0.20$ vs $36.66 \pm 0.43 \mathrm{~g}$ TAE $/ 100 \mathrm{~g}$ extract), causing it to be more anti-oxidative than the mature rind with the $\mathrm{EC}_{50}$ of $5.56 \pm 0.12 \mu \mathrm{g} / \mathrm{ml}$ compared to $10.94 \pm$ $0.06 \mu \mathrm{g} / \mathrm{ml}$ of the mature rind. The mature rind, containing more $\alpha$-mangostin, possessed relatively better antibacterial activity, with the MIC and MBC against $P$. 
Table 2: Some of the xanthones present in G. mangostana (Khumsupan \& Gritsanapan, 2013)

\begin{tabular}{lll}
\hline Name & $\begin{array}{l}\text { Plant parts } \\
\text { Pericarp, } \\
\text { Whole fruit, }\end{array}$ & $\begin{array}{l}\text { - Antioxidant } \\
\text { - Antimicrobial (M. tuberculosis, } \\
\text { S. aureus, P. acnes) } \\
\text { Stem, Arils, Seed }\end{array}$ \\
\hline Beta-manti-inflammatory
\end{tabular}

acnes being $15.63 \mu \mathrm{g} / \mathrm{ml}$, compared to $15.63 \mu \mathrm{g} / \mathrm{ml}$ (MIC) and $31.25 \mu \mathrm{g} / \mathrm{ml}(\mathrm{MBC})$ of the young rind (Pothitirat, Chomnawang, Supabphol, \& Gritsanapan, 2009).

\section{Chemical and biological stability}

Stability is one of the most important aspects that should be taken into consideration when choosing a compound for formulation. G. mangostana extract has proven to be quite stable, with the active constituent remaining more than $90 \%$ after the accelerated stability study. A study was conducted where the ethanol extract was kept in amber glass vials and aluminum foil bag at three different temperatures, $4-8^{\circ} \mathrm{C}, 25-28^{\circ} \mathrm{C}$ and $45^{\circ} \mathrm{C}$. After 120 days, there were no significant changes to the $\alpha$-mangostin content, antioxidant activity and antibacterial activity in all samples (Pothitirat, Pithayanukul, Chomnawang, Supabphol, \& Gritsanapan, 2009).

\section{Conclusion}

Aside from being tasty and nutritious, mangosteen also possesses many biological properties that could be useful in the field of medicine. Although many medicinal aspects of mangosteen have been investigated, the research on the anti-acne activity is still much limited. Like most medicinal herbs, a lot of research has to still be done to fully grasp its complexity. Certainly, mangosteen harbors practical potential, as evident in ethnopharmacology and supported studies, to be developed into many products. Plausibly, the ethanol extract of the rind, which possesses relatively strong anti-acne activity, could be formulated and commercialized to alleviate the bacterial-resistant epidemic.

\section{References}

Chomnawang, M. T., Surassmo, S., Nukoolkarn, V. S., \& Gritsanapan, W. (2005). Antimicrobial effects of Thai medicinal plants against acne-inducing bacteria. Journal of Ethnopharmacology, 101(1-3), 330-333. PMid:16009519. http://dx.doi.org/10.1016/j.jep.2005.04.038

Chomnawang, M. T., Surassmo, S., Nukoolkarn, V. S., \& Gritsanapan, W. (2007). Effect of Garcinia mangostana on inflammation caused by Propionibacterium acnes. Fitoterapia, 78(6), 401-408. $\quad$ http://dx.doi.org/10.1016/i.fitote.2007.02.019 PMid:17644272

Farnworth, R. N., \& Bunyapraphatsara, N. (1992). Garcinia mangostana Linn. in Thai medicinal plants. Prachachon Bangkok.

Jung, H. A., Su, B. N., Keller, W. J., Mehta, R. G., \& Kinghorn, A. D. (2006). Antioxidant xanthones from the pericarp of Garcinia mangostana (Mangosteen). Journal of Agriculture and Food Chemistry, 54(6), 2077-2082. http://dx.doi.org/10.1021/jf052649z PMid:16536578

Khumsupan, P., \& Gritsanapan, W. (2013). Selected Thai medicinal plant for the treatment of acne: Garcinia mangostana Linn. In M. L. Elsaie (Ed.), Acne: Etiology, Treatment options and Social Effects (pp. 51-60). New York: Nova Science Publishers, Inc.

Obolskiy, D., Pischel, I., Siriwatanametanon, N., \& Heinrich, M. (2009). Garcinia mangostana L.: a phytochemical and pharmacological review. Phytotherapy Research, 23(8), 1047-1065. PMid:19172667

Peres, V., Nagem, T. J., \& de Oliveira, F. F. (2000). Tetraoxygenated naturally occurring xanthones. Phytochemistry, 55(7), 683-710. http://dx.doi.org/10.1016/S0031-9422(00)00303-4 
Pothitirat, W., Chomnawang, M. T., \& Gritsanapan, W. (2008). Anti-acne inducing bacteria activity and alpha-mangostin content of Garcinia mangostana fruit rind extracts from different provenience. Songklanakarin Journal of Science and Technology, 31(1), 41-47.

Pothitirat, W., Chomnawang, M. T., Supabphol, R., \& Gritsanapan, W. (2009). Comparison of bioactive compounds content, free radical scavenging and anti-acne inducing bacteria activities of extracts from the mangosteen fruit rind at two stages of maturity. Fitoterapia, 80(7), 442-447. http://dx.doi.org/10.1016/j.fitote.2009.06.005 PMid:19524646

Pothitirat, W., Chomnawang, M. T., Supabphol, R., \& Gritsanapan, W. (2010). Free radical scavenging and anti-acne activities of mangosteen fruit rind extracts prepared by different extraction methods. Pharmaceutical Biology, 48(2), 182-186. http://dx.doi.org/10.3109/13880200903062671 PMid:20645837

Pothitirat, W., Pithayanukul, P., Chomnawang, M. T., Supabphol, R., \& Gritsanapan, W. (2009). Biological and chemical stability of mangosteen fruit rind extract. Functional Plant Science and Biotechnology, 3(1), 16-18.

Saralamp, P., Chuakul, W., Temsiiririkkul, R., \& Clayton, T. (1996). Medicinal plants in Thailand. Bangkok. Thailand: Amarin printing and publishing public Co., Ltd.

Somsri, S., \& Manassakorn, C. (2006). Amazing Thai Mangosteen (N. Chomchalow Ed.). Bangkok, Thailand: Horticultural Research Institute (HRI) - Department of Agriculture (DOA).

United States Department of Agriculture (2014). Garcinia mangostana L. Retrieved from http://plants.usda.gov/core/profile?symbol=GAMA10

Vieira, L. M., \& Kijjoa, A. (2005). Naturally-occurring xanthones: recent developments. Current Medicinal Chemistry, 12(21), 2413-2446 http://dx.doi.org/10.2174/092986705774370682 PMid:16250871. 